\title{
Influence of local and large-scale weather events and timing of breeding on tropical roseate tern reproductive parameters
}

\author{
Jaime A. Ramos ${ }^{1, *}$, Anna M. Maul ${ }^{2, * *}$, Vickie Ayrton ${ }^{2, * * *}$, Ian Bullock ${ }^{2, * * * *}$, \\ Janet Hunter ${ }^{2, * * * * *}$, John Bowler ${ }^{2, * * * *}$, Gill Castle $^{2, * * * * *}$, Rob Mileto $^{2, * * * * * *}$, Carlos Pacheco $^{1}$ \\ ${ }^{1}$ Institute of Marine Research (IMAR), Departamento de Zoologia, Universidade de Coimbra, 3004-517 Coimbra, Portugal \\ ${ }^{2}$ Aride Island Nature Reserve, c/o Post Office, Grande Anse, Praslin, Seychelles
}

\begin{abstract}
We analysed the effects of local- (sea-surface temperature [SST] and windspeed) and large- (multivariate El Niño index) scale weather conditions and timing of breeding on reproductive parameters of tropical roseate terns Sterna dougallii on Aride Island, Seychelles, using up to 17 years of data. The size of the breeding population and initiation of breeding were negatively and positively correlated, respectively, with both SST and the multivariate El Niño index for the laying season (MayJune). It is the first time that an El Niño index obtained for the Pacific Ocean is shown to be correlated with reproductive parameters of seabirds in the Indian Ocean. Hatching success decreased significantly with later initiation of breeding. Virtually no chicks fledged when breeding started in June ( $40 \%$ of the years monitored). We suggest that oceanographic conditions over a relatively large scale have an influence on tern arrival date to the breeding grounds and that SST around the breeding colony influences the number of birds that attempt to breed. Despite the influence of factors such as predatory fish on food availability, this influence appears to be overridden by the importance of weather events and oceanographic conditions, which are likely to determine marine productivity. This study suggests that ecosystem-level phenomena appear to be important in shaping the population dynamics of tropical roseate terns.
\end{abstract}

KEY WORDS: Roseate tern $\cdot$ El Niño $\cdot$ Seabird ecology $\cdot$ Tropical seabirds $\cdot$ Productivity $\cdot$ Timing of breeding

\section{INTRODUCTION}

Climatic fluctuations have a great influence on reproductive parameters and morphological traits of animal

*Email: jramos@ci.uc.pt

Present addresses:

${ }^{* *}$ Amundsengasse 5, $8010 \mathrm{Graz}$, Austria

***17 Upton Road, Norwich NR4 7PB, United Kingdom

****Tegfan, Caerbwdi, St. David's, Dyfed SA62 6QP, United Kingdom

*****Shepherd's Cottage, Heylipol, Tiree PA77 6TY, Inner Hebrides, Scotland, UK

${ }^{* * * * * *} 61$ Copthorne Road, Shrewsbury SY3 8NW, Shropshire, United Kingdom and plant populations (Grant \& Grant 1989, Myneni et al. 1997, Wikelski \& Trillmich 1997, Grant et al. 2000). This subject has recently received considerable attention as evidence for an increase in global climatic change. For example, European birds and plants have consistently been reproducing earlier over the past 2 to 3 decades (Crick et al. 1997, Myneni et al. 1997, McCleery \& Perrins 1998). Climate variation is, at least in part, related to variation in natural large-scale atmospheric phenomena, of which the El Niño Southern Oscillation (ENSO) is one of the best known. The El Niño drives periodical fluctuations in temperature and precipitation and is correlated with global and regional temperature fluctuations (Schlesinger \& Ramankutty 1994). 
El Niño events cause widespread breeding failures and mortality of marine organisms, notably seabirds in the Pacific Ocean, because of food shortages caused by raised sea temperatures and reduced ocean upwelling (Nelson 1983, Barber \& Chavez 1986, Glynn 1988, Megyesi \& Griffin 1996). Despite the claimed worldwide influence of El Niño on the phenology and reproductive parameters of seabirds in other areas of the world (Schreiber 1994), the subject remains poorly studied. Variation in food supply has a marked impact on breeding parameters and productivity of small seabirds such as terns (Monaghan et al. 1989), because there is little leeway in their energy budgets and they spend a greater proportion of their time foraging than do larger species (Pearson 1968). When foraging costs are increased, the priority of adult breeding seabirds is to keep their body mass at a high level, at the expense of provisioning for their offspring (Weimerskirch et al. 2000). Therefore, increasing levels of food stress are expected to reduce provisioning, lead to desertion of eggs and chicks, or for the birds to refrain from breeding (Chastrel et al. 1995, Ramos 2001).

Increases in breeding effort, for example in the duration of foraging, can act to buffer seabirds against environmental perturbation. Such behavioural plasticity has been shown to mask the effects of food shortage on chick growth and breeding success (Uttley et al. 1994) of temperate seabirds. However, effects of food stress on breeding parameters is more marked in tropical seas due to strong food shortages during the breeding season (Ramos 2000, 2002a). For example, mass mortality of chicks at an advanced stage of development, negative growth rates and low productivity are common for tropical roseate terns Sterna dougallii in the Great Barrier Reef, Pacific Ocean, and Aride Island of the Seychelles, Indian Ocean (Milton et al. 1996, Ramos 2001).

Local weather events influence breeding performance of temperate terns. Langham (1968) found that growth rates of roseate tern chicks, which positively reflect the fishing success of their parents, were inversely correlated with wind speed. For common terns Sterna hirundo, and sandwich terns S. sandvicensis, increasing wind speed and sea surface conditions facilitate prey capture within a certain range (Dunn 1973). For tropical populations, biotic features, notably predatory fish that drive prey close to the water surface (Shealer 1996, Ballance \& Pitman 2000, Ramos 2000), appear to be the most important factors facilitating fish capture, but the effects of weather on fishing success have not been investigated. Because ENSO drives interannual fluctuations in weather variables such as sea-surface temperature (SST) and prevailing winds (Wolter 1987, Wolter \& Timlin 1993), it also has the potential to determine marine productivity. El Niño events occur at sufficiently short intervals to provide a natural replicated experiment with which to evaluate the effects of environmental factors on reproductive parameters.

In this study we searched for possible effects of (1) local- and large-scale weather phenomena and (2) timing of breeding on reproductive parameters of a population of roseate terns on Aride Island using up to 17 years of data. In particular we addressed the following questions: (1) What is the magnitude of variation in the breeding population and parameters of reproductive performance over the study period? (2) Are those fluctuations related to fluctuations in the ENSO and local weather? (3) What is the relationship between timing of breeding and other reproductive parameters? Timing of breeding may be viewed as a coarse index of food availability, because previous studies have demonstrated a causal relationship between later breeding and lower food availability in terns (Safina et al. 1988).

\section{MATERIALS AND METHODS}

Breeding population. Aride Island $\left(4^{\circ} 10^{\prime} \mathrm{S}\right.$, $55^{\circ} 40^{\prime} \mathrm{E}$ ) covers 73.2 ha and is a Royal Society for Nature Conservation reserve. Most roseate terns on the island nest close to rocks or logs under a tree canopy of Mapou Pisonia grandis, on average $0.5 \mathrm{~m}$ from their nearest neighbour (Ramos 1998). The number of active nests, defined as nests with an incubating bird or intact egg(s), were counted in the main colony by a team of observers traversing the nesting area in marked transects $18 \mathrm{~d}$ after the first egg was laid (1996 to 2000), and by direct counts of the number of incubating birds from selected vantage points (1986 to 1995; Bowler et al. 2002). In 1997 the breeding population was estimated using the 2 methods, and both produced similar figures (800 to 900 vs 845 pairs, respectively; Ramos 2002b). From 1997 to 2000, the main colony counts were amended to account for the percentage of clutches missed, using data from quadrats where all nests were known, because eggs are well camouflaged in the leaf litter. Between 14.9 and 28.8\% of the nests were missed during the main count (Ramos 2002b). However, non-amended counts were used in this paper because these are comparable with the counts from vantage points (Ramos 2002b).

Breeding parameters. Until 1996, chick survival and productivity (number of chicks fledged per breeding pair) were estimated from regular visits to viewpoints to count the number of eggs and chicks in the sampling areas. At the end of the breeding season, sampling areas and the rest of the colony were surveyed for dead chicks (Maul 1998). Hatching success (percentage of eggs that hatched) and fledging success (percentage of hatched chicks that fledged) were obtained from nests 
mapped at the time of egg laying and monitored every 1 to $3 \mathrm{~d}$ from a permanent hide and/or vantage point (1993 to 2001), and from daily visits to study quadrats (1997 to 2001). Very similar values of productivity were obtained from both mapped and marked nests (Ramos 2001, 2002b), and from marked/mapped nests versus estimated number of chicks fledged within the whole colonies (see 'Results', Table 3). Without disturbance, most chicks remained at their nest sites until they fledged or died (Ramos 2001). During daily visits of up to 30 min to the study quadrats (1997 to 2001), eggs were measured (length and breadth accuracy to $0.1 \mathrm{~mm})$, chicks were ringed and weighed both at hatching and again on each encounter (Ramos 2001). In 2-egg clutches, eggs were classified as ' $a$ ' (the first egg laid or the first egg to hatch) and 'b'. Egg external volume $\left(V, \mathrm{~cm}^{3}\right)$ was calculated from egg length $(L$, $\mathrm{cm})$ and breadth $(B, \mathrm{~cm})$ using the equation $V=0.512 \times$ $L B^{2}$ (Stonehouse 1966). Likely causes of chick mortality, notably intraspecific aggression by adults and infestation by ticks Amblyomma loculosum, were recorded for chicks in the study quadrats and noted in a sampling area from a permanent hide (Ramos et al. 2001). Daily visits to study quadrats lasted throughout the whole nestling period and most chicks were weighed until they were 15 to $20 \mathrm{~d}$ old. Based on studies of temperate roseate terns all chicks $>5 \mathrm{~d}$ old that were not losing mass were expected to fledge (Nisbet et al. 1990). However, as temporary food shortages occur often in the tropics and lead to the death of halfgrown chicks (Ramos 2001) we searched for dead chicks, in and around the study quadrats, until chicks were about to fledge. We also took into account that a maximum of $20 \%$ of the nestlings were infested with female ticks, and from those only $37.5 \%$ survived (Ramos et al. 2001). Chick food-provisioning was assessed daily from a permanent hide ( $\mathrm{n}=8$ to 10 chicks) for a $2 \mathrm{~h}$ period ( 7 to $9 \mathrm{~h}$ in 1997 and 1998) and a $1 \mathrm{~h}$ period ( 8 to $9 \mathrm{~h}$ in 2001), and expressed as the mean number of prey items brought to chick per hour.

The multivariate El Niño index. ENSO is a natural, large-scale environmental perturbation, occurring over the tropical Pacific Ocean. During El Niño events, the west to east winds and marine currents over the tropical Pacific break down, leading to an increased SST and a reduction of marine productivity. In this study we used a measure of the strength of the El Niño called the multivariate El Niño index (MEI). The MEI data were obtained from Klaus Wolter of the National Center for Atmospheric Research in Boulder, Colorado (details available on home page: http://www.ncar.ucar. edu/) and are also available from the first author on request. This index is the first principal component of sea-level pressure, zonal and meridional components of the surface wind, SST, surface air temperature and total cloudiness fraction of the sky assembled from multiple locations in the tropical Pacific Ocean. The MEI is computed separately for each of 12 sliding bimonthly seasons (December-January, January-February and so on; Wolter 1987, Wolter \& Timlin 1993). Negative values of the MEI represent the cold El Niño phase, i.e. La Niña.

Local weather data. We used IGOSS (Integrated Global Ocean Services Systems; Reynolds \& Smith 1994) monthly mean SSTs blended from ship, buoy and bias-corrected satellite data obtained from the home page of IGOSS, integrated global Ocean Services system (available at www.ingrid.ldgo.columbia.edu/ SOURCES/.IGOSS), for the closest location of Aride Island $\left(4^{\circ} \mathrm{S}, 55^{\circ} \mathrm{E}\right)$. Daily mean and maximum wind speed for the period June-July in 1997 to 2001 (measured in knots; 1 knot $=1.85 \mathrm{~km} \mathrm{~h}^{-1}$ ) were obtained from the meteorological station on Mahé airport, about $40 \mathrm{~km}$ from Aride. We assumed that these values represent the average temperature and wind speed conditions in the area surrounding Aride Island.

Statistical analyses. We checked for a correlation between the number of breeding pairs and the MEI averaged over the austral summer months of September/October in year $\mathrm{n}-1$ to April/May in year $\mathrm{n}$. This is justified because variation in environmental conditions experienced during the winter for migrant birds may influence their breeding ecology (Marra et al. 1998), especially timing of breeding (Forchhammer et al. 1998). Even if roseate terns do not directly experience climate variations correlated with the MEI, an effect of this index could be mediated by an effect of the El-Niño on marine productivity affecting abundance of prey populations. We also tested for a correlation between monthly mean SST during the breeding season (May to August) and the size of the breeding population, because the number of birds that attempt to breed may depend on local variations in SST, which in turn could be related to marine productivity and abundance of prey populations.

We checked for correlations between roseate tern timing of breeding and productivity (= number of fledglings per breeding pair) and monthly values of (1) SST and (2) MEI, during the breeding season (May to August). We tested for a correlation between wind speed and the average number of prey items brought to chicks per hour in 1997, 1998 and 2001, since the capture of prey by adult terns may be influenced by wind speed (Dunn 1973).

We also looked for trends in breeding statistics in relation to timing of breeding. A negative relationship between timing of breeding and clutch size, egg size, hatching success and fledging success is expected because delayed initiation of breeding in terns has been related with a decrease in these parameters 
(Safina et al. 1988). All tests were 2-tailed. We used Pearson's correlation coefficient in all correlations except those involving the number of breeding pairs, for which the Spearman rank correlation coefficient was used, because these data showed a highly skewed distribution. All tests were performed with the package Statistica for Windows (StatSoft 1995).

\section{RESULTS}

\section{Breeding statistics in relation to oceanographic conditions}

Over the study period the breeding-population size showed a non-significant decrease ( $\mathrm{rs}=-0.25, \mathrm{n}=16$, $\mathrm{p}>0.05$ ). Timing of breeding, as assessed by the date of the first egg laid, and productivity did not change systematically $(r=0.004$ and $r=-0.33$, respectively, $p>$ 0.05; Table 1) from 1985 to 2001. Of the weather data used in this study, only temperature in July showed a significant increase over time $(r=0.53, p<0.05)$. The MEI for May-June was significantly correlated with SST in May $(\mathrm{r}=0.61, \mathrm{p}<0.01)$ and June $(\mathrm{r}=0.75, \mathrm{p}<$ 0.001), and the MEI for June-July was significantly correlated with the SST in July $(r=0.70, p<0.01)$.

The size of the breeding population was significantly inversely correlated with temperature in June ( $\mathrm{rs}=$ $-0.58, \mathrm{p}<0.02, \mathrm{n}=16$, Fig. 1). The correlations

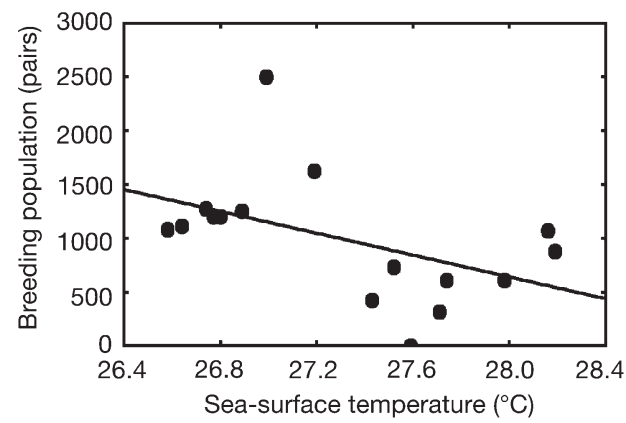

Fig. 1. Sterna dougallii. Relationship between the number of breeding pairs and the sea-surface temperature in June (data for the years 1986 to 2001)

between the breeding population and mean SST in May and July were also negative but non-significant ( $\mathrm{rs}=-0.36$ and -0.29 , respectively, $\mathrm{p}>0.05, \mathrm{n}=16$ ). There was also a negative but non-significant trend between the MEI for the period September-October in year $\mathrm{n}-1$ to April-May in year $\mathrm{n}$ and the size of the breeding population in year $\mathrm{n}(\mathrm{rs}=-0.38, \mathrm{n}=16, \mathrm{p}>$ 0.05).

Timing of breeding and productivity were not significantly correlated with the austral summer MEI. However, timing of breeding showed a significant positive trend with the MEI for May-June (the laying season, Fig. 2) but not with the SST for May and June. Neither

Table 1. Sterna dougallii. Population estimates, date of first egg and breeding success for roseate tern on Aride between 1985 and 2001. Productivity is the number of fledged chicks per breeding pair estimated from counts of fledged chicks. When there was a range in the estimate of the breeding population and the number of chicks fledged, the productivity was calculated based on the mean values. Data from 1991 and 1992 taken from Lidstone-Scott (1993). nd: no data

\begin{tabular}{|c|c|c|c|c|c|c|c|}
\hline \multirow[t]{2}{*}{ Year } & \multicolumn{3}{|c|}{ Breeding pairs per colony } & \multirow{2}{*}{$\begin{array}{l}\text { Total breeding population } \\
\text { (breeding pairs) }\end{array}$} & \multirow{2}{*}{$\begin{array}{l}\text { Date of } \\
\text { first egg }\end{array}$} & \multirow{2}{*}{$\begin{array}{l}\text { Number of } \\
\text { chicks fledged }\end{array}$} & \multirow[t]{2}{*}{ Productivity } \\
\hline & Lodge Glade & Bois Tortue & Western Woodlands & & & & \\
\hline 1985 & & & & nd & 1 June & 0 & 0.00 \\
\hline 1986 & & & & $2000-3000$ & 19 May & 0 & 0.00 \\
\hline 1987 & 800 & 50 & 800 & $1500-1750$ & 5 June & 0 & 0.00 \\
\hline 1988 & 550 & 30 & 500 & 1080 & 12 May & $75-150$ & 0.10 \\
\hline 1989 & 400 & 15 & 700 & 1115 & 29 May & $558-583$ & 0.51 \\
\hline 1990 & 500 & 25 & 750 & 1275 & 28-29 Мау & 316 & 0.25 \\
\hline 1991 & 0 & 0 & 0 & 0 & No laying & 0 & 0.00 \\
\hline 1992 & 170 & 20 & 420 & 610 & 4 June & $25-30$ & 0.05 \\
\hline 1993 & 50 & 25 & 240 & 315 & 4 June & 141 & 0.45 \\
\hline 1994 & 0 & 22 & 404 & 426 & 19 May & 203 & 0.48 \\
\hline 1995 & 0 & 11 & 600 & 611 & 29 May & 300 & 0.49 \\
\hline 1996 & 0 & 13 & 1242 & 1255 & 13 May & $400-500$ & 0.36 \\
\hline 1997 & 0 & 7 & $863(1106)^{\mathrm{a}}$ & $876(1119)^{\mathrm{a}}$ & 1 June & $<10$ & 0.004 \\
\hline 1998 & 0 & 8 & $954(1151)^{\mathrm{a}}$ & $1068(1265)^{\mathrm{a}}$ & 17 May & $678-708$ & 0.55 \\
\hline 1999 & 0 & 4 & $1108(1257)^{\mathrm{a}}$ & $1200(1349)^{\mathrm{a}}$ & 14 June & 0 & 0.00 \\
\hline 2000 & 0 & 3 & $604(1292)^{a}$ & $612(680)^{\mathrm{a}}(1200)^{\mathrm{b}}$ & 3 June & 15 & 0.01 \\
\hline 2001 & 0 & 4 & $729(817)^{\mathrm{a}}$ & $733(824)^{\mathrm{a}}$ & 16 May & 170 & 0.21 \\
\hline
\end{tabular}




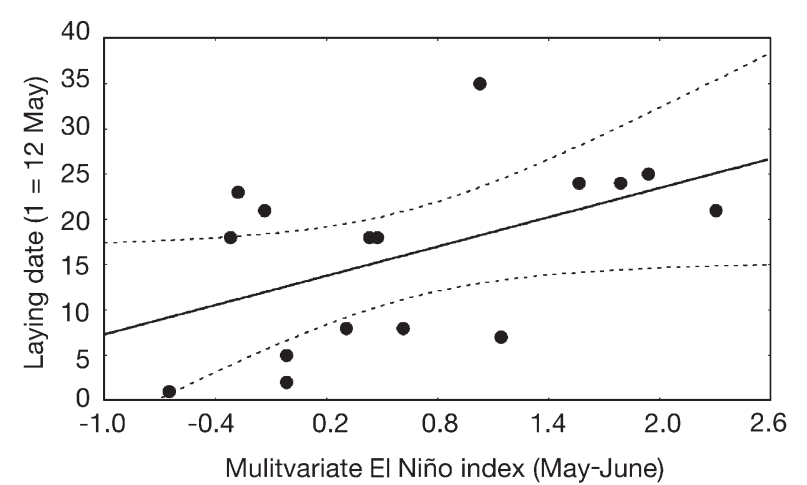

Fig. 2. Sterna dougallii. Relationship between timing of breeding and the multivariate El Niño index for May-June $\left(y=12.70+5.38 x, p<0.05, R^{2}=0.25\right)$. Regression line $\pm 95 \%$ confidence limits are shown

the SST nor monthly values of the MEI for May, July and August correlated significantly with productivity. However, it should be noted that during strong El Niño seasons (MEI > 1 for June-July, the fledging season) the productivity was virtually null for 4 out of $5(80 \%)$ years, whereas during normal to mild seasons (MEI $<1$ for June-July) the productivity was null for 5 out of 12 $(42 \%)$ years (Fisher exact test, non-significant). These data suggest a positive effect of the MEI on the timing of breeding of roseate terns and a weak effect on their productivity. However, it should be acknowledged that these kind of analyses have low power.

The influence of wind speed on the number of prey items brought to chicks was not significant for any of the study years (after an outlier of 1998 was removed; Fig. 3).

\section{Breeding statistics in relation to timing of breeding}

There was a slight increase in egg size from 1997 to 2001 but it was only significant between 2001 and the previous years (Table 2). Mean clutch size, hatching success and fledging success varied greatly among years (Table 3). The differences in clutch size, egg size, hatching success and fledging success were not caused by biases in sampling with respect to location within the colony (see Ramos 2002) since the same parts of the colony were studied each year. The predicted negative relationship between timing of breeding and parameters of breeding success was significant $(p<0.05)$ for hatching success in the Bois Tortue colony, and approached significance $(p<0.06)$ for hatching success in the Western Woodlands colony (Table 3).

There was a negative but non-significant correlation between initiation of breeding and productivity $(\mathrm{r}=$ $-0.41, \mathrm{p}<0.10, \mathrm{n}=17$; Fig. 4); 1991 was included in the analysis with a laying date of $1 \mathrm{~d}$ more than the latest breeding season because birds never laid in that year
Table 2. Sterna dougallii. Sizes of a-eggs (see 'Materials and methods' for explanation) laid by roseate terns on Aride in 1997, 1998, 1999 and 2001. Columns sharing the same letter did not differ significantly (all comparisons $\mathrm{p}<0.05$, Newman-Keuls test)

\begin{tabular}{|ccccc|}
\hline Year & $\mathrm{n}$ & Length $(\mathrm{cm})$ & Width $(\mathrm{cm})$ & Volume $\left(\mathrm{cm}^{3}\right)$ \\
\hline 1997 & 145 & $41.13 \pm 1.71^{\mathrm{b}}$ & $28.65 \pm 1.27^{\mathrm{b}}$ & $17.32 \pm 1.63^{\mathrm{b}}$ \\
1998 & 132 & $40.76 \pm 1.71^{\mathrm{b}}$ & $28.99 \pm 0.87^{\mathrm{b}}$ & $17.57 \pm 1.43^{\mathrm{b}}$ \\
1999 & 127 & $41.06 \pm 2.03^{\mathrm{ab}}$ & $28.99 \pm 1.00^{\mathrm{ab}}$ & $17.71 \pm 1.73^{\mathrm{b}}$ \\
2001 & 131 & $41.89 \pm 5.40^{\mathrm{a}}$ & $29.81 \pm 6.24^{\mathrm{a}}$ & $18.20 \pm 1.38^{\mathrm{a}}$ \\
ANOVA & $F_{3,531}=3.2$ & $F_{3,531}=3.1$ & $F_{3,530}=7.7$ \\
& $(\mathrm{p}<0.05)$ & $(\mathrm{p}<0.05)$ & $(\mathrm{p}<0.05)$ \\
& & & \\
\hline
\end{tabular}

(Table 1). The comparison between productivity when breeding started in May and in June was highly significantly different $\left(t_{15}=3.01, \mathrm{p}<0.01\right.$, Table 1$)$. Although some newly hatched chicks were killed by intraspecific adult aggression (Ramos 2001) and ticks (Ramos et al. 2001), the proximate cause of the virtually null breeding success in 1985 to 1988, 1992, 1997 and 2000 (7 out of 17 years that productivity was monitored; Table 1) was starvation of half-grown chicks. In 1991 birds refrained from breeding (Table 1) and in 1999 virtually all adults abandoned their eggs before hatching.

\section{DISCUSSION}

An important concern is whether the 2 different methods of census and monitoring of productivity used over the study period influenced the population data. However, for both parameters, when the 2 methods were used in conjunction, very similar values were obtained (Table 3). On Aride, roseate terns nest under a tree canopy (Ramos 1998) and chicks remain at their

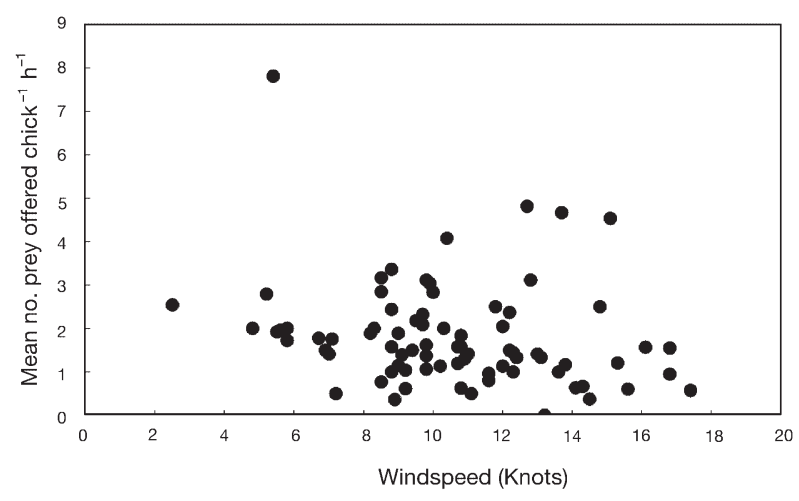

Fig. 3. Sterna dougallii. Prey delivery rates in relation to mean wind speed. The relationship was not significant $(r=-0.15$, $p=0.18, n=80$ ) when the outlier on the far left was removed (from 10 July 1998 when upwelling was observed along the reef edge of the south coast; Ramos 2000) 
Table 3. Sterna dougallii. Breeding statistics for roseate terns on Aride Island, between 1993 and 2001, for the colonies Bois Tortue (B.Tortue) and Western Woodlands (W.Woods). For some years productivity for the Western Woodlands colony was assessed with 2 methods: using the number of mapped and/or marked nests in sampling areas of the colony, and counting the number of chicks fledged within the whole colonies from regular visits to viewpoints (shown in parentheses; $\mathrm{r}$ [between both methods] $=0.96, \mathrm{p}<0.001$ ). Breeding parameters for the Western Woodlands are slightly different from those presented in earlier publications because we assembled data from all sampling areas (hide area, study quadrats and small woodland sub-colonies). The Pearson correlation shown is between egg laying initiation and each breeding parameter (the percentages of the hatching and fledging success were arcsine-transformed). ns: non-significant; nd: no data

\begin{tabular}{|c|c|c|c|c|c|c|c|c|}
\hline \multirow[t]{2}{*}{ Year } & \multirow[t]{2}{*}{$\begin{array}{l}\text { Egg-laying } \\
\text { initiation }\end{array}$} & \multirow{2}{*}{$\begin{array}{c}\text { Mean clutch } \\
\text { size } \\
(\mathrm{cm})\end{array}$} & \multicolumn{2}{|c|}{$\begin{array}{c}\text { Hatching success } \\
\text { No. of eggs ( } \% \text { hatched) }\end{array}$} & \multicolumn{2}{|c|}{$\begin{array}{l}\text { Fledging success } \\
\text { No. of chicks (\% fledged) }\end{array}$} & \multicolumn{2}{|c|}{ Productivity } \\
\hline & & & B.Tortue & W.Woods & B.Tortue & W.Woods & B.Tortue & W.Woods \\
\hline 1993 & 4 Jun & nd & $10(70.0)$ & $20(70.0)$ & $7(69.0)$ & $14(60.0)$ & 0.50 & $0.40(0.50)$ \\
\hline 1994 & 19 May & nd & $22(77.3)$ & $404(84.2)$ & $17(82.4)$ & $340(55.6)$ & 0.63 & $-(0.47)$ \\
\hline 1995 & 29 May & 1.08 & $11(63.6)$ & 55 (69.1) & $7(71.4)$ & $38(73.7)$ & 0.45 & $0.56-$ \\
\hline 1996 & 13 May & 1.55 & $20(75.0)$ & $261(67.8)$ & $15(60.0)$ & $177(30.0)$ & 0.69 & $0.32(0.36)$ \\
\hline 1997 & $1 \mathrm{Jun}$ & 1.05 & $7(43.0)$ & $310(60.3)$ & $3(0.0)$ & $187(5.3)$ & 0.00 & $0.01(0.01)$ \\
\hline 1998 & 17 May & 1.27 & $10(90.0)$ & $359(78.0)$ & $9(44.4)$ & $280(57.0)$ & 0.50 & $0.58(0.54)$ \\
\hline 1999 & 14 Jun & 1.16 & $5(0.0)$ & 241 (4.6) & $0(0.0)$ & $11(0.0)$ & 0.00 & $0.00(0.00)$ \\
\hline 2000 & 3 Jun & 1.03 & $3(66.7)$ & $50(48.0)$ & $2(100.0)$ & $24(4.2)$ & 0.67 & $0.01(0.02)$ \\
\hline 2001 & 16 May & 1.13 & $7(42.8)$ & $148(47.3)$ & $3(33.3)$ & $70(61.4)$ & 0.25 & $0.32(0.21)$ \\
\hline $\mathrm{r}$ & & -0.61 & -0.66 & $-0.64^{\mathrm{a}}$ & -0.29 & -0.60 & -0.52 & $-0.56(-0.50)$ \\
\hline $\mathrm{p}<$ & & ns & 0.05 & ns & ns & ns & ns & ns \\
\hline
\end{tabular}

nest sites until they fledge or die (Ramos 2001). The terns could be approached quite closely without disturbance, and with frequent visits to vantage points that surround the colonies it was possible to count incubating birds and monitor chick survival accurately.

This study revealed that the number of breeding pairs and timing of breeding were significantly affected by climatic fluctuations at the start of the breeding season (May-June). Weather effects on timing of breeding and breeding population size were mediated differently: a large-scale climatic fluctuation measured by the MEI apparently affected timing of breeding, and the local SST apparently affected the size of the breeding population. This suggests that oceanographic conditions over a relatively large scale

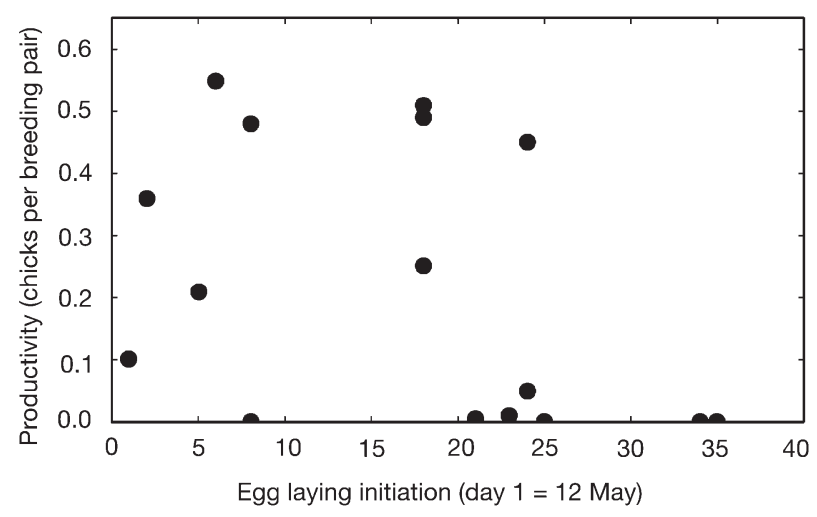

Fig. 4. Sterna dougallii. Relationship between roseate tern productivity and timing of breeding on Aride Island, Seychelles should influence arrival on the breeding grounds and initiation of egg laying, and that SST around the breeding colony influences the number of birds that will lay eggs. The MEI for May-June was significantly correlated with local SST for June. This suggest that local SST is an important weather variable in explaining the size of the breeding population and timing of breeding, but the covariation between MEI and local SST makes it difficult to separate the effects of these 2 factors. However, local SST per se did not correlate with timing of breeding, suggesting that large-scale weather effects are potentially more important to explain timing of breeding, and, as a consequence, roseate tern productivity.

The link between SST and roseate tern reproduction should be food supply. One should expect that as temperature decreases along the SE monsoon, the marine productivity should reach a certain threshold, enabling breeding to commence (effect at a colony level) but the number of birds that will lay eggs will be affected by the extent of the decrease in the SST (effect at an individual level). Wind speed did not influence food delivery to chicks. In temperate roseate terns the effect of wind on chick food provisioning is variable, as Dunn (1975) found an inverse correlation between wind speed and chick growth for roseate terns breeding in Coquet Island (England) in 1968 but not in 1969. An important factor affecting food availability for tropical seabirds, including roseate terns, appears to be the presence of predatory fish driving prey to the surface (Shealer 1996, Ballance \& Pitman 1999, Ramos 2000). We have no data to comment 
on the factors that influence presence or absence of predatory fish but their occurrence around Aride could also be related to lower SST.

Studies of larids have shown that food supply is an important determinant of breeding parameters such as laying date (Safina et al. 1988), clutch size (Sydeman et al. 1991, Pons \& Migot 1995) and egg volume (Hiom et al. 1991, Bolton et al. 1992). The relationship between timing of breeding and parameters of breeding success, although negative as predicted, was significant only for hatching success (albeit during incubation when reproductive costs are relatively small). When birds began nesting in June $(40 \%$ of the years that productivity was monitored), they were successful in only 1 year. Moreover, second nesting attempts after first complete breeding failures were recorded throughout this study, and in other tropical roseate tern populations, but all have been unsuccessful (Milton et al. 1996, Ramos 2002b). Altogether this suggests a strong selection for early breeding in tropical roseate terns.

Earlier breeding has been correlated with higher food availability for temperate terns (Safina et al. 1988). Elsewhere, it has been experimentally demonstrated that food supply influences reproduction through the timing of breeding, clutch size and the number of breeding attempts (Perrins \& McCleery 1989, Sanz \& Moreno 1995, Nager et al. 1997). We could not manipulate levels of food abundance. However, high annual variation in SST might be a proxy measure of food resources, allowing an assessment of this factor through long-term monitoring and statistical comparisons. Although we do not have independent data to validate this hypothesis, a lower sea surface temperature is associated with an increase of marine productivity (Schmelzer 2000). In fact, the breeding season of most seabirds in the Seychelles occurs when the seasonal shift in the divergence zone between the South Equatorial Current and the Equatorial Counter-current lies within the latitude of Central Seychelles (Feare 1981, Diamond \& Prys-Jones 1986). This shift may correspond to an increase of both the primary productivity and abundance of predatory fish (Le Corre 2001).

Birds that do not breed as soon as food conditions permit (Perrins 1970) may experience appreciable fitness loss (van Noordwijk et al. 1995, Nilson \& Svensson 1996, Wiggins et al. 1998). As further evidence for this Ramos (2001, 2002a) described a trade-off between early laying and clutch and/or egg size for roseate terns on Aride Island. A pressure for early breeding should be important to explain the fact that timing of breeding is the sole reproductive parameter most influenced by climate change (Przybylo et al. 2000 and references within).

When food supply fluctuates unpredictably throughout the breeding season, females should lay as many eggs as their body condition allows and opt for a brood-reduction strategy later in the season if conditions do not improve (Bolton et al. 1992). The fact that birds laid larger clutches in years of earlier breeding agrees with this view. Roseate terns also laid the largest eggs in 2001, the earliest breeding season (for the years when egg size was monitored). During periods of low food availability, as assessed by chick foodprovisioning rates, foraging parents were prepared to leave young chicks unguarded despite the fact that chicks could be attacked and killed by adults of neighbouring territories (Ramos 2001). Chick foodprovisioning suggests that local food supplies show large daily fluctuations (Ramos 2000). Lack of predatory fish to drive prey to the surface (Ramos 2000) may contribute to explain intermediate periods of food shortage. However, this study suggests that breeding failures are connected with later breeding, which, in turn, are related to high MEI values for May-June. Therefore, despite some influence of other factors, such as presence of predatory fish, weather conditions likely influencing marine productivity at the start of the breeding season (May-June on Aride) appear to be the most important factor determining roseate tern breeding success.

In contrast to studies on temperate terrestrial birds that found an advancement in laying (Crick et al. 1997, McCleery \& Perrins 1998), apparently explained by an increase in spring temperatures, the negative relationship found in this study between MEI and timing of breeding means that an increase in SSTs might delay laying by tropical seabirds, with a consequent negative effect on productivity. Seabird species are adapted to unpredictable foraging conditions and show a high degree of plasticity in timing of breeding and chick developmental patterns (Ricklefs 1983). Therefore, seabird population-level responses to climate indices might be a result of phenotypic plasticity (Przybylo et al. 2000).

This study shows also that ecosystem-level mechanisms appear to be important in shaping the population dynamics of tropical roseate terns. Thus, climate variation is also important for the recovery of the roseate tern subpopulations (Nisbet \& Spendelow 1999) and therefore for the entire species.

Acknowledgements. We are indebted to Dr. James Cadbury of the Royal Society for Nature Conservation for permission to carry out research work on Aride and for financial assistance to travel there. The friendship and help of the wardens of Aride and volunteers is acknowledged. Klaus Wolter, from the University of Colorado at Boulder, provided the MEI data. Wind-speed data were kindly provided by John Nevill from the Ministry of Environment and Transport, Republic of the Seychelles. Three anonymous referees made constructive comments which greatly improved a previous version of the manuscript. 


\section{LITERATURE CITED}

Ballance LT, Pitman RL (1999) Foraging ecology of tropical seabirds. In: Adams NJ \& Slotow RH (eds) Proc 22nd Int Ornithol Congr, Durban. Birdlife South Africa, Johannesburg, p 2057-2071

Barber RT, Chavez FP (1986) Ocean variability in relation to living resources during the 1982-83 El Niño. Nature 319: 2279-2285

Bolton M, Houston D, Monaghan P (1992) Nutritional constraints on egg formation in the Lesser black-backed Gull: an experimental study. J Anim Ecol 61:521-532

Bowler J, Betts M, Bullock I, Ramos JA (2002) Seabird population trends on Aride Island Nature Reserve, Seychelles 1988-2000. Waterbirds 25:26-38

Chastrel OH, Weimerskirch H, Jouventin P (1995) Body condition and seabird reproductive performance: a study of three petrel species. Ecology 76:2240-2246

Crick HQP, Dudley C, Glue DE, Thompson DL (1997) UK birds are laying eggs earlier. Nature 388:526

Diamond AW, Prys-Jones RP (1986) The biology of terns nesting at Aldabra Atoll, Indian Ocean, with particular reference to breeding seasonality. J Zool 210:527-549

Dunn E (1973) Changes in fishing ability of Terns associated with windspeed and sea surface conditions. Nature 244: 520-521

Dunn E (1975) The role of environmental factors in the growth of tern chicks. J Anim Ecol 44:743-754

Feare CJ (1981) Breeding schedules and feeding strategies of Seychelles seabirds. Ostrich 52:179-185

Forchhammer MC, Post E, Stenseth N (1998) Breeding phenology and climate. Nature 388:526

Glynn P (1988) El Niño-Southern Oscillation 1982-1983: nearshore population, community, and ecosystem responses. Annu Rev Ecol Syst 19:309-345

Grant PR, Grant BR (1989) Evolutionary dynamics of a natural population: the large cactus finch of the Galapagos. The University of Chicago Press, Chicago

Grant PR, Grant BR, Keller LF, Petren K (2000) Effects of El Niño events on Darwin's finch productivity. Ecology 81: 2442-2457

Hiom L, Bolton M, Monaghan P, Worrall D (1991) Experimental evidence for food limitation of egg production in gulls. Ornis Scandinavica 22:94-97

Langham NP (1968) The biology of terns, Sterna spp. PhD thesis, University of Durham

Le Corre M (2001) Breeding seasons of seabirds at Europa Island (southern Mozambique channel) in relation to seasonal changes in the marine environment. J Zool 254: 239-249

Lidstone-Scott R (1993) Aride Island Scientific Report 1991-92. Royal Society for Nature Conservation, Lincoln, UK

Marra P, Hobson PKA, Holmes RT (1998) Linking winter and summer events in a migratory bird by using stable-carbon isotopes. Science 282:1884-1886

Maul AM (1998) Breeding biology and monitoring of 3 seabird species (brown noddy Anous stolidus, lesser noddy Anous tenuirostris, roseate tern Sterna dougallii) on Aride Island, Seychelles, with special comments on breeding behaviour and biometrics of the brown noddy. PhD thesis, Karl-Franzens University, Graz, Austria

McCleery RH, Perrins CM (1998) Temperature and egglaying trends. Nature 391:30-31

Megyesi JL, Griffin CR (1996) Breeding biology of the Brown Noddy on Tern Island, Hawaii. Wilson Bull 1108: 317-334

Milton DA, Smith GC, Blaber SJM (1996) Variable success in breeding of the roseate tern Sterna dougallii on the northern Great Barrier. Emu 96:123-131

Monaghan P, Uttley JD, Burns MD, Thaine C, Blackwood J (1989) The relationship between food supply, reproductive effort and breeding success in Arctic terns Sterna paradisaea. J Anim Ecol 58:261-274

Myneni RB, Keeling CD, Tucker CJ, Asrar G, Nemani RR (1997) Increased plant growth in the northern high latitudes from 1981 to 1991. Nature 386:698-702

Nager RG, Rugger C, van Noordwijk AJ (1997) Nutrient or energy limitation on egg formation: a feeding experiment in great tits. J Anim Ecol 66:495-507

Nelson JB (1983) Contrast in breeding strategies between some tropical and temperate marine Pelecaniformes. Stud Avian Biol 8:95-114

Nilsson JA, Svensson E (1996) The cost of reproduction: a new link between current reproductive effort and future reproductive success. Proc R Soc Lond B 263:711-714

Nisbet ICT, Spendelow JA (1999) Contribution of research and management and recovery of the roseate tern: review of a twelve-year project. Waterbirds 22:239-252

Nisbet ICT, Burger J, Safina C, Gochfeld M (1990) Estimating fledging success and productivity in roseate terns (Sterna dougallii). Colon Waterbirds 13:85-91

Pearson TH (1968) The feeding biology of seabird species breeding on the Farne islands, Northumberland. J Anim Ecol 37:521-552

Perrins CM (1970) The timing of the birds' breeding seasons. Ibis 112:242-255

Perrins CM, McCleery RH (1989) Laying date and clutch size in the great tit. Wilson Bull 101:236-253

Pons JM, Migot P (1995) Life history strategies of the herring gull: changes in survival and fecundity in a population subjected to various feeding conditions. J Anim Ecol 64: 592-599

Przybylo R, Sheldon BC, Merila J (2000) Climatic effects on breeding and morphology: evidence for phenotypic plasticity. J Anim Ecol 69:395-403

Ramos JA (1998) Nest-site selection by roseate terns breeding on Aride Island, Seychelles. Colon Waterbirds 21:438-443

Ramos JA (2000) Characteristics of foraging habitats and chick food provisioning by tropical roseate terns. Condor 102:795-803

Ramos JA (2001) Seasonal variation in reproductive measures by tropical roseate terns: previously undescribed breeding patterns in a seabird. Ibis 143:83-91

Ramos JA (2002a) Spatial patterns of breeding parameters in tropical roseate terns differ from temperate seabirds. Waterbirds 25:285-294

Ramos JA (2002b) The contribution of 18 years of monitoring and research for the conservation of roseate terns on Aride Island. Phelsuma 10:17-27

Ramos JA, Bowler J, Davis L, Middleton C (2001) Activity patterns and effect of ticks on the growth and survival of tropical roseate tern nestlings. Auk 118:709-716

Reynolds RW, Smith TM (1994) Improved global sea surface temperature analysis. J Clim 7:929-948

Ricklefs RE (1983) Avian postnatal development. In: Farner DS, King JR, Parkes KC (eds) Avian biology, Vol VII. Academic Press, New York, p 1111-1183

Safina C, Burger J, Gochfeld M, Wagner RW (1988) Evidence for prey limitation of common and roseate tern reproduction. Condor 90:852-859

Sanz JJ, Moreno J (1995) Experimentally induced clutch size enlargements affect reproductive success in the pied flycatcher. Oecologia 103:358-364

Schlesinger ME, Ramankutty N (1994) An oscillation in the 
global climate system of period 65-70 years. Nature 367: $723-726$

Schmelzer I (2000) Seals and seascapes: covariation in Hawaiian monk seal subpopulations and the oceanic landscape of the Hawaiian archipelago. J Biogeogr 27:901-914

Schreiber EA (1994) El Niño-Southern Oscillation events may be affecting your field data as they alter weather patterns worldwide. Research notes on Avian Biology: selected contributions from the 21st International Ornithological Congress. J Ornithol 135:210

Shealer DA (1996) Foraging habitat use and profitability in tropical roseate terns and sandwich terns. Auk 113: $209-217$

StatSoft (1995) Statistica for Windows: users' manual. Tulsa, OK

Stonehouse B (1966) Egg volumes from linear dimensions. Emu 65:227-228

Sydeman WJ, Penniman JF, Penniman TM, Pyle P, Ainley DJ (1991) Breeding performance in the western gull: effects of parental age, timing of breeding and year in relation to food availability. J Anim Ecol 60:135-149

Uttley JD, Walton P, Monaghan P, Austin G (1994) The effects of food abundance on breeding performance and adult time budgets of guillemots Uria aalge. Ibis 136:205-213

Editorial responsibility: Otto Kinne (Editor),

Oldendorf/Luhe, Germany van Noordwijk AJ, McCleery RH, Perrins CM (1995) Selection for the time of great tit breeding in relation to caterpillar growth and temperature. J Anim Ecol 64:451-458

Weimerskirch H, Prince GPA, Zimmerman L (2000) Chick provisioning by the yellow-nosed albatross Diomedea chlororhynchos: response of foraging effort to experimentally increased costs and demands. Ibis 142:103-110

Wiggins DA, Part T, Gustafsson L (1998) Timing of breeding and reproductive costs in collared flycatchers. Auk 116: 1063-1067

Wikelski M, Trillmich F (1997) Body size and sexual size dimorphism in marine iguanas fluctuate as a result of opposing natural and sexual selection: an island comparison. Evolution 51:922-936

Wolter K (1987) The Southern Oscillation in surface circulation and climate over the tropical Atlantic, Eastern Pacific, and Indian Oceans as captured by cluster analysis. J Clim Appl Meteorol 26:540-558

Wolter K, Timlin MS (1993) Monitoring ENSO in COADS with a seasonally adjusted principal component index. In: Proc 17th Climate Diagnostics Workshop. NOAA/NMC/CAC NSSL, Oklahoma Climate Survey, CIMMS and the School of Meteor, University of Oklahoma, Norman, OK, p 52-57

Submitted: January 15, 2002; Accepted: July 19, 2002

Proofs received from author(s): October 18, 2002 